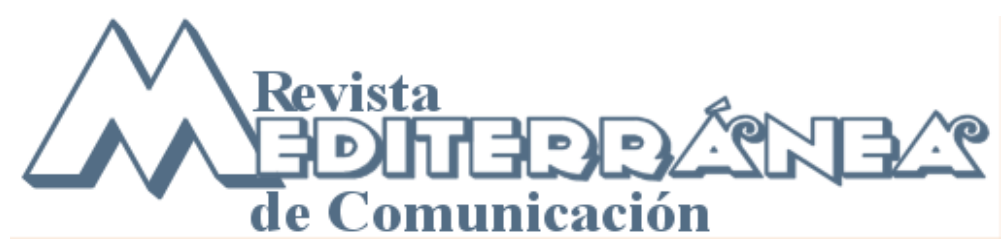

\title{
Análisis del mensaje publicitario sobre la audiencia segmentada de la IPTV
}

\section{Analysis of the advertising message on the segmented audience of IPTV}

\author{
Enrique Carrasco Molina \\ Doctor en Comunicación Audiovisual por la Universidad de La Laguna. Tenerife. España. \\ $\mathrm{PhD}$ in Audiovisual Communication Studies. University of La Laguna. Tenerife.Spain. \\ enrique.carrasco.molina@gmail.com
}

\section{Resumen}

Este artículo se centra en el análisis de algunas de las innovadoras alternativas que ofrece Internet, en simbiosis con la 'televisión a la carta', como la IPTV. Se estudia el nuevo sistema como atractiva plataforma publicitaria para anunciantes, y cómo éstos se benefician de la nueva y determinante segmentación de las audiencias. Se traza una panorámica sobre la importante penetración que ha tenido Internet en la propia vida de las personas, condicionando su acercamiento a cualquier fenómeno comunicativo. Se efectúa un trabajo de campo mediante la descripción y la cuantificación de alternativas que registran los mejores resultados en el aspecto publicitario dentro del mismo formato IPTV. Se estudian dos de los sistemas de IPTV que hoy día funcionan en España (Imagenio, Yatv), y se analizan metodologías del discurso publicitario que aprovechan el recurso de la cercanía para mejorar sus posibilidades de impacto, impulsando el consumo de un producto concreto. Se exploran, asimismo, los nuevos diseños del mensaje publicitario que rompen con el concepto de spot tradicional asociado, sobre todo, a las cadenas de televisión generalista.

\section{Abstract}

This article focuses on the analysis of some of the innovative ways the Internet offers, in symbiosis with the VOD (video on demand, TV systems which allow users to select and watch/listen to video or audio content on demand), such as IPTV. The new system is studied as an attractive advertising platform for advertisers, and how they benefit from the new and crucial segment of the audience. It draws a panoramic view of the important insight that has had Internet in the lives of individuals, determining their approach to any communicative phenomenon. The article describes and quantifies the best alternatives to implement results in the advertising aspect within the IPTV format. We study two IPTV systems that operate in Spain today (Imagenio, YATV) and advertising discourse analysis methodologies that leverage the use of closeness to improve their impact by promoting the consumption of a particular product. We explore also the new creative designs that break with the concept of associated traditional spot, especially for generalist television.

Forma de citar este artículo: Carrasco Molina, Enrique (2011) "Análisis del mensaje publicitario sobre la audiencia segmentada de la IPTV", en Revista Mediterránea de comunicación, 2, pp. 72-102. Recuperado el día de mes de año (añadir enlace) 


\section{Palabras claves}

IPTV; TV por Internet; audiencia segmentada; marketing de cercanía; interactividad; España.

\section{Key Words}

IPTV; Internet TV; segmented audience; proximity marketing; interactive;Spain.

Sumario: 1.Introducción. 2. Método. 3. Internet un poderoso medio de comunicación. 4. La llamada de los jóvenes. 5. Nuevas oportunidades de negocio publicitario en la red. 6. TV por Internet, una iniciativa que rompe el exceso de reclamos. 7. Alta especialización. 8. IPTV en banda ancha. 9. Un concepto que parece difícil pero no lo es. 10. Video-streaming. 11. Más posibilidades publicitarias. Marketing de cercanía. 12. Imagenio. 13. Yatv. 14. Mensajes publicitarios en Yatv. 14.1. Anuncios de apertura. 14.1.a. "Ahorro Hipercor". 14.1.b. Cortometraje "Pequeño Palacio", de la Escuela TAl. 14.2. Anuncios por canales. 14.3. Canales Orange. 15. Conclusiones. 16. Referencias bibliográficas. 17. Notas.

Summary: 1.Introduction. 2. Method. 3. Internet, a powerful media 4. The call of the young people. 5. Advertising business opportunities in the network. 6. Internet TV, a move that breaks the excess of claims. 7. Highly specialized. 8. IPTV in wide broadband. 9. A concept that seems difficult but it is not. 10. Video-streaming. 11. More advertising opportunities. Proximity marketing. 12. Imagenio. 13. YATV. 14. YATV advertisements. 14.1. Opening announcements. 14.1.a. "Saving Hipercor." 14.1.b. Short film "Little Palace", TAl School. 14.2. Advertisements channels. 14.3. Orange channels. 15. Conclusions. 16. References.17. Notes.

\section{Introducción}

Los espacios de la comunicación han cambiado sustancialmente en muy pocos años en virtud de varios factores, entre otros, la exitosa irrupción de Internet, una revolución sin precedentes que ha dado un giro de $360^{\circ}$ al concepto que tradicionalmente se tenía del intercambio informativo entre personas.

La transformación de la atención de la audiencia a favor de atractivas fórmulas de interactuación con los propios emisores, y la generación de mensajes propios que construyen nuevos marcos de feedback instantáneo son otros condicionantes de un hasta ahora inédito universo comunicativo sin fronteras.

Se ha impuesto un nuevo modo de asomarnos a un fenómeno comunicativo caracterizado en buena parte por las contribuciones de los receptores: desde el llamado periodismo ciudadano en blogs, o la determinación del desenlace de reality shows a través del envío de sms que nominan o expulsan a concursantes, [1] hasta los concurridos foros especializados, programas de comunicación en redes internas de empresas, o chats a invitados dentro de un mismo gestor de correos electrónicos (como gmail), entre otros ejemplos.

Todo ello choca frontalmente con un enfoque convencional, unidireccional, que han mantenido durante décadas algunos medios de comunicación como la televisión, que desde hace unos años trata de reinventarse. 
Ahora es el mismo telespectador-internauta el que elige, el que toma sus decisiones, el que se auto-programa y reclama el mensaje audiovisual que le apetece en cada momento (vídeo a demanda); incluso es el coautor del contenido en no pocas ocasiones.

Los programadores informáticos, por otro lado, ávidos generadores de nuevas ideas, como los promotores de las redes sociales, se colocan ahora en situaciones hasta ahora desconocidas, como el descubrimiento de inexploradas fórmulas de patrocinio y publicidad que logren rentabilizar sus exitosas apuestas.

Por todos estos condicionantes, los actores que intervienen en la justificación de una campaña de publicidad (anunciante y ejecutor de la publicidad, bien sea diseñador/ra autónomo/a o agencia de publicidad) ponen sobre la mesa de trabajo los nuevos gustos, las últimas tendencias, las necesidades que tienen los distintos targets en función de edades, condicionantes económicos, sexos y motivaciones.

El rápido y cambiante contexto tecnológico, las exigencias de información que sugieren las propias audiencias, y las ágiles posibilidades de acceso a contenidos muy diversos, establecen un contexto de actuación en el que los publicistas despejan dudas, prácticamente, con la misma celeridad que determina en todo momento el ritmo del mercado.

Aunque a menudo divergen las esferas de lo creativo y lo financiero, ambas partes necesitan encontrar el equilibrio [2], y, en un caldo de cultivo donde entran en simbiosis los contenidos televisuales personalizados con la agilidad de Internet, el optimismo se amplifica.

La IPTV, como cualquier otra presentación de formato que hibrida televisión y web, trata de escudriñar las mejores alternativas que concilian sus especificidades técnicas con las opciones más atractivas desde el punto de vista de la creatividad publicitaria y las posibilidades económicas de cada anunciante.

La respuesta de la IPTV en términos de aceptación por parte de los telespectadores es cada vez más destacada.

S. Millán, M. Jiménez y A. Ruiz del Árbol, en el periódico Cinco Días (2007), subrayaban un dato contundente ya en 2007:

"La generalización de la banda ancha ha provocado la irrupción de un negocio en torno a las nuevas formas de ver televisión a través de Internet. Según un estudio de la consultora iSuppli, los ingresos de la televisión por internet (IPTV) aumentarán este año un 177\% hasta 3.260 millones de dólares".

El entorno IPTV, como veremos, es muy proclive a delimitar sus piezas publicitarias en estrechísima consonancia con sus contenidos a demanda, es decir que responden con fidelidad extrema a los gustos de contenidos que los usuarios piden en cada momento.

Suscribimos en este sentido la opinión de la tesis de Carlos Cotelo Oñate (2010) sobre el sistema IPTV, reseñando que tanto el control sobre el acceso a los contenidos como la capacidad de comunicación bidireccional entre el cliente y el operador permiten el desarrollo de modelos de negocio directamente relacionados con el contenido ofertado. 
Y nos afirmamos muy en la línea de Javier Gálvez Guerrero (2007), quien se manifiesta muy claro a la hora de diferenciar las ventajas que brinda la IPTV por encima del broadcast convencional.

Gálvez indica que mientras los canales generalistas tratan de interactuar con el televidente estableciendo mecanismos simples que no pasan de la clásica llamada para emitir votaciones o participar en sorteos, o el envío de los típicos sms para fines similares, el protocolo IPTV permite ofrecer un abanico muy extenso de aplicaciones: desde los contenidos bajo demanda, a la configuración de perfiles de usuario que permiten la personalización de la publicidad, la posibilidad de comprar artículos comerciales fácilmente o la opción de crear un canal personal por el que es posible distribuir contenidos privados a amigos y familiares.

El citado autor incide en algunas de las claves diferenciadoras de las plataformas IPTV frente a los sistemas de televisión convencionales, y en líneas sucesivas comprobamos no sólo el motivo por el que muchos usuarios seleccionan una fórmula distinta de acercarse a un mensaje audiovisual: llegamos más allá pues descubrimos cómo muchas firmas interesadas en destinatarios muy diversos convergen en el innovador medio.

Así, ventajas de la IPTV como la disponibilidad inmediata del vídeo bajo demanda (VOD) que permite una mayor libertad al cliente para poder visualizar los contenidos de acuerdo a sus preferencias y disponibilidad, desembocan en un tema aludido en párrafos posteriores, la construcción de una "televisión a la carta" muy moderna que concede un protagonismo hasta ahora inusitado al usuario.

Con todo ello, publicistas y anunciantes observan un nuevo filón a explotar, un medio que combina la segmentación, con la diversificación y la participación de la audiencia, conformándose perfiles de usuario mucho más claros que en otros formatos, y Gálvez (2007: 109) lo explicita nítidamente:

"Otro de los servicios que ofrece la tecnología en la que se sustentan los sistemas de IPTV es la creación de perfiles de usuario. Con la definición de estos perfiles cada usuario asocia a su identidad una serie de preferencias que ayudan a determinar patrones de segmentación de mercado, resultando útiles para que la efectividad de los anuncios publicitarios emitidos en los servicios de IPTV se vea notablemente incrementada".

En el presente estudio nos planteamos, entre otras, varias cuestiones:

¿Es la apuesta de la IPTV una fórmula de penetración en la audiencia tan nueva como efectiva? ¿Hasta dónde invierten las marcas destinando parte de sus partidas a insertar publicidad en el nuevo formato? ¿Es la personalización de contenidos tan útil para diseñar una estrategia publicitaria rentable?

Y a lo largo del artículo perseguimos la teoría de que, analizando como ejemplos los mensajes publicitarios de estos dos sistemas en España, se determina una gran oportunidad de negocio para anunciantes que dirigen su mirada hacia un mercado no ya emergente, sino fulgurante, que es el que consume de forma contumaz el mensaje audiovisual combinado con la televisión y la tecnología de Internet.

Tratando entonces de enriquecer la escasa bibliografía existente, y los pocos análisis de contenidos de este formato al que aludimos, nos proponemos en este artículo dar a conocer un poco mejor las interioridades de la IPTV, por una parte, como innovadora plataforma de 
contenidos a demanda, y, por otra, como portadora de mensajes publicitarios rentables que tratan de alcanzar en todo momento el mejor su posicionamiento.

\section{Método}

Este artículo analiza y cuantifica pormenorizadamente cómo el mensaje publicitario puede optimizar sus resultados adoptando nuevos formatos como la IPTV, televisión sobre Protocolo IP, un formato a la carta que se beneficia de sus programaciones sobre audiencias exclusivas y segmentadas.

Se comienza trazando una panorámica sobre la importante penetración que ha tenido Internet en la propia vida de las personas, condicionando su acercamiento a cualquier fenómeno comunicativo.

Se hace alusión también al entrecruzamiento informativo que se genera la red, a su gran éxito en las distintas franjas de edad pero, sobre todo, a su demanda entre las nuevas generaciones, debido, en gran parte, a la influencia de las redes sociales.

Y entrando en la explicación de lo que supone el formato exclusivo de la IPTV, se toman como ejemplo sistemas de IPTV que actualmente se pueden contratar en España (Imagenio, Yatv), y se estudian métodos y presentaciones que aprovechan el recurso de la cercanía (mensajes para telespectadores seleccionados) para mejorar sus posibilidades de alcance, potenciando el consumo de un artículo o contenido determinado.

Se realiza un trabajo de campo descriptivo que se detiene en las fórmulas que hoy por hoy tienen más salida en la comunicación publicitaria vinculada a este formato relativamente nuevo que cada vez tiene más seguidores en distintos países del mundo.

Se exploran los nuevos diseños de presentación que rompen con el concepto de spot tradicional vinculado estrechamente al discurso de los canales de televisión generalista.

Y se descubren finalmente nuevas vías de introducción del producto en el discurso televisual (product placement) [3] beneficiándose esta operación de la versatilidad audiovisual que incorpora el soporte de Internet.

Yatv no tiene hoy día una cuantificación de audiencia publicada probablemente por criterios comerciales particulares, mientras Imagenio va liberando información periódica sobre su evolución, sobre todo por el optimismo que manifiesta la compañía dado el incremento notable del número de abonados (incluso en tiempos de crisis). La última cuantificación conocida de abonados Imagenio asciende a 800.000, a 30 de septiembre de 2010. [4]

Los parámetros de análisis que se han barajado, siempre dependiendo del tipo de anuncio o promoción comentados, tanto en el caso de Imagenio, como en el de Yatv, son los siguientes:

a) Guión-Locución: Se contrastan aspectos relacionados con el lenguaje empleado por el creativopublicista, el tono de la locución, o si la presentación de diálogos y eslóganes es eficaz y atractiva. 
b) Diseño-Montaje Audiovisual: Tanto el diseño de rótulos insertados en el producto audiovisual, como el montaje de imágenes/sonidos, y su sentido rítmico y artístico son vitales para el aumentar el impacto del spot. Se comentan algunas características que se aprecian sobre este particular.

c) Perfil o Target de la audiencia: Los contenidos se concluyen en un conjunto de perfiles o targets que atienden precisamente a la propia segmentación de las audiencias, muy especializadas por franjas de edad, nivel adquisitivo y tendencias a la hora de escoger espacios programáticos.

d) Intencionalidad del Anunciante: Beneficiándose de los perfiles de consumidores que habitualmente demandan estas plataformas televisivas, el anunciante planifica, en tándem con la agencia, una estrategia perfectamente adaptada al gusto del destinatario final.

e) Emplazamiento de producto: Se citan ciertas habilidades para introducir mensajes publicitarios dentro de los propios contenidos.

\section{Internet, un poderoso medio de comunicación}

Internet lleva en nuestro país más de veinte años asentado no sólo como poderoso instrumento para generar nuevas posibilidades en las relaciones comunicativas de las personas. El nuevo medio se ha convertido, en apenas unos años, en una de las principales vías de comunicación, compitiendo abiertamente con los grandes mass media -prensa, radio, televisión-, y combinando sus fórmulas de penetración en el mercado a través de una hábil interrelación de los mensajes generados por aquéllos.

En este sentido, es curioso analizar cómo infinidad de sitios web incluyen actualmente, en tiempo real, o mediante descargas rápidas, cortes radiofónicos, spots publicitarios, informativos televisivos, recortes de prensa digitalizados, entrevistas, anuncios estáticos o dinámicos, [5] vídeos enviados por usuarios, programación de televisión online, y otros muchos recursos que transforman la visión del mundo con un imaginativo (aunque a veces caótico) cóctel de formatos que juega con pantallas dentro de pantallas.

El contingente de usuarios de la red crece día a día en una cadencia vertiginosa. Lucía Valero (Valero, 2010: 6) introduce su estudio sobre el mercado de Internet en Italia destacando el ingente volumen de usuarios en 2009:

"Efectuando un análisis de los abonados a Internet a nivel mundial, se observa la prevalencia del consumo de banda ancha. De hecho, este tipo de consumo creció considerablemente entre los años 2006 y 2009, pasando de un 58\% de facturación a un 75\%. En 2009, el número de usuarios del servicio de banda ancha alcanzó los 476 millones".

Un referente estadístico sacado a la luz a finales de 2010 (Global Entertainment and Media Outlook, PricewaterhouseCoopers) augura una impresionante progresión del consumo Internet, los videojuegos y la televisión de pago hasta 2013:

"Internet, los videojuegos y la televisión de pago liderarán el crecimiento de la industria española de Medios de Comunicación, Ocio y Entretenimiento en los próximos cinco años, que crecerá una media anual acumulada de un 3,8\%, según el informe Global Entertainment and Media Outlook que desde hace diez años elabora PricewaterhouseCoopers. El mercado de acceso a Internet $(6,4 \%)$ y los videojuegos (4,9\%) serán las industrias que más crecerán en 2010. 
El estudio incluye previsiones de crecimiento de 12 segmentos -acceso a Internet; publicidad en Internet; televisión de pago; publicidad en televisión; discográfica; cinematográfica; videojuegos; edición de revistas; edición de periódicos; entre otras- y un análisis detallado de la situación de cada uno de estos sectores en el mundo, en Europa y en España. Internet (acceso a la red, $13,3 \%$, y la publicidad online, $6,7 \%)$, los videojuegos $(6,9 \%)$ y la televisión de pago $(5,5 \%)$, que incluye TDT, satélite, cable e IPTV, liderarán el crecimiento del mercado español hasta 2013".

Las causas del éxito de la comunicación web podrían dividirse básicamente en dos: las económicas y las psicológicas. En cuanto a las primeras, está muy clara la relación oferta-precio. Se podría decir que casi cualquiera tendría acceso a una conexión siempre y cuando encontrara una terminal, O PC cerca, conexión telefónica, o beneficiándose de áreas Wi-Fi gratuitas de determinados inmuebles como edificios oficiales, cadenas de restaurantes, recepciones de hoteles, etcétera. En lugares alejados de núcleos poblacionales, los módems USB de Internet Móvil, o los Smartphones [6], solucionan nuestras demandas con coberturas casi siempre garantizadas.

También, en espacios distantes de ciudades o pueblos, se aprecia notablemente el rendimiento que proporcionan las muy manejables terminales IPad (la famosa tableta de Apple), o Blackberry, entre otras. Todas estas posibilidades no son excesivamente caras para el bolsillo del ciudadano medio.

El joven que aún no trabaja puede conectarse al ordenador de sus padres, cuando éstos no lo están utilizando, o al de un amigo, o el que encuentra en algún aula de un centro educativo, o simplemente acudiendo a la Biblioteca de su Universidad.

Enrique de la Rica explica claramente que entre los motivos que han potenciado la expansión de Internet entre los millones de usuarios registrados (cuantía siempre en constante aumento), son, por un lado, la constante demanda de información y, por otro, la bajada de los precios en los equipos informáticos:

"Con el apetito aparentemente insaciable de información que tiene el ser humano y la proliferación de ordenadores motivada por la caída de los precios, primero en las empresas y ahora en los hogares, Internet se está convirtiendo en una de las primeras fuentes de información y de comunicación mundiales". (De la Rica, 2000: 3)

En cuanto a las causas psicológicas del éxito de la comunicación online nos encontramos con distintos comentarios de expertos y con opiniones que convergen en ciertos aspectos.

Existen teorías que entran de lleno en el campo de diagnóstico de los psicólogos, que asocian el ingente flujo de los chats, por ejemplo, a un intercambio informativo bidireccional en el que intervienen básicamente personas tímidas que se refugian en la seguridad del hogar y frente una pantalla de ordenador.

Este colectivo, en el que abundan adolescentes o adultos con problemas de habilidades sociales, asumen nuevas y fantasiosas identidades, y suplen los miedos de enfrentarse al cara a cara comunicativo cobijándose en la discreción del PC.

Diego Levis incide sobre este particular y detalla: 
"En Internet las consecuencias inmediatas de las palabras y de las acciones son poco visibles. La opacidad de la pantalla genera en muchas personas una desacostumbrada desinhibición que les permite decir-hacer aquello que difícilmente dicen o hacen habitualmente. El anonimato y la ausencia física del otro permite mostrar sin "riesgos" aparentes, pliegues de uno que se acostumbra ocultar en la vida cotidiana". (Levis, 2006: 148).

\section{La llamada de los jóvenes}

No hay duda del poder de atracción que ejercen la tecnología, y sus elementos identificativos colaterales -entre otros, la presentación, la imagen de marca, las prestaciones que ejercen liderazgo y producen cada vez más demanda, y el intercambio de información inmediato- entre el público joven.

La interactividad y sus representaciones populares (ventanas emergentes, emoticonos, etc.), así como el enorme poder que supone el crear contenidos propios (incluyendo imagen y sonido) y subirlos (o colgarlos, según el argot que corresponda) se han convertido en poco tiempo en un signo de los tiempos, en una realidad innata y consustancial a la comunicación misma. Todo ello se refuerza en un caldo de cultivo muy propio para la gente joven, individuos que aún se encuentran en un entorno pre-laboral caracterizado por los descubrimientos y la importancia asignada al entretenimiento.

En un estudio reciente, Galán y Del Pino conceden atención, igualmente, a la gigantesca irrupción de las redes sociales para activar aún más un juego mediático online en el que participan incansablemente jóvenes enganchados a la informática y a las TIC:

“ (...) las generaciones más jóvenes se conforman como uno de los targets más atractivos para los programadores, por su posición como potenciales consumidores y su gran afición a las tecnologías. Es natural para ellos tener varias pantallas abiertas al mismo tiempo, cambiar rápidamente el foco de atención (...), y elegir qué quieren ver y cuándo quieren verlo".

(Elena Galán Fajardo y Cristina del Pino Romero, 2010: 3)

\section{Nuevas oportunidades de negocio publicitario en la red}

Precisamente en el terreno publicitario, las estrategias más vanguardistas del marketing y posicionamiento empresarial global estrenan hoy sí y, mañana, también, alternativas a la costosa publicidad institucional de los soportes convencionales (vallas, cine, televisión, prensa y revistas, y radio).

Internet abre sus rápidos y virtuales engranajes de visualización a golpe de "click" en tribunas y nichos comerciales altamente competitivos, y encima, a costes realmente atractivos. La red se ha hecho incluso aún más fuerte como salida promocional de compañías afectadas por la crisis económica (la que más, y la que menos, ha "sentido" repercusiones directas o colaterales). Es evidente que la debacle económica no puede ignorar la necesidad de comunicación de productos y ofertas. El caso contrario colapsaría el sistema productivo.

Los datos son contundentes y sobre esta base se hacen nuevas reflexiones en torno a la rentabilidad; los anunciantes reorientan sus planes de medios destinando mayores partidas a la audiencia online. 
Algunas estadísticas, como las referenciadas por La Asociación Europea de Publicidad Interactiva (EIAA), (2010) aseguran que ya Internet es el medio más consumido por los españoles:

“ (...) La innovación tecnológica junto con las numerosas opciones que tienen los usuarios para conectarse a la red han conseguido aumentar significativamente el uso de Internet en España hasta las 13,6 horas semanales, frente a las 13 horas que se dedican a la televisión. Esta cifra nos situa, además, como el quinto país europeo con mayor consumo de Internet".

Europa Press matiza en www.eleconomista.es (26 de abril de 2011) que la inversión publicitaria crecerá en España un 1,7\% (hasta los 5.947,3 millones de euros), en 2011, gracias al impulso de Internet, según una estadística prevista por Arena Media. Esta fuente indica asimismo que "pese a este avance de Internet y el retroceso de los medios escritos, las televisión continuará siendo en 2011 el principal medio en cuanto a inversión publicitaria con unos ingresos de 2.476,8 millones de euros y los periódicos ocuparán el segundo puesto, con 1.092,9 millones de euros".

Con estos datos en la mano, confirmamos el extraordinario poder que tiene el formato televisivo y la multiplicación de posibilidades cuando el consumo audiovisual se potencia a través de Internet dada la masiva conectividad que se da en nuestro país.

Pero, además constatamos, gracias a informes de poco tiempo a esta parte, que entre los distintos tipos de 'presentación' que tienen los mensajes publicitarios son, precisamente, los spots, los que más auge de consumo han experimentado dentro de los propios soportes digitales.

El dato lo comprobamos en un balance que ha dado a conocer el Interactive Advertising Bureau (www.iabspain.net), en marzo de 2011, Asociación que representa al sector de la publicidad interactiva en España.

Esta organización asegura que la inversión publicitaria en soportes digitales rozó los 800 millones de euros en 2010, destacando, respecto a los formatos, "la casi duplicación de la representatividad de la publicidad en spots de vídeo, que alcanzó el 3,1\% en 2010 frente al 1,7\% en 2009".

\section{TV por Internet, una iniciativa que rompe el exceso de reclamos}

En este postrero caldo de cultivo amparado por los nuevos medios, situándose Internet como herramienta catalizadora, sin duda tienen más éxito las iniciativas que logran romper el "exceso de reclamos", evidentemente, aquéllas que neutralizan esa abrumadora carga de mensajes a la que se somete cada individuo conviviendo con las simples emisiones publicitarias que llegan a su retina a diario.

En el presente contexto de necesidad de diferenciación se ha desarrollado en los últimos años una televisión mucho más personalizada y cercana, "a la carta", la que podemos visionar a través del ordenador conectándonos a un sitio web especializado.

Buscamos pues el consumo inmediato de un producto que nos devuelva 'cero interferencias' (es decir, que nos libre de los aburridos cortes publicitarios de las grandes cadenas generalistas o privadas) y nos brinde concentrados mensajes que satisfagan nuestras necesidades informativas $y$, por qué no, publicitarias, eso sí, siempre bajo el enfoque de nuestras demandas de acceso. 
Según el último estudio Navegantes en la Red de la Asociación para la Investigación de Medios de Comunicación (AIMC), publicado el 25 de febrero de 2011, Internet es en estos momentos la principal fuente de información para dos tercios de los 40.000 individuos encuestados (en un sondeo efectuado desde el 19 de Octubre hasta el 12 de Diciembre de 2010).

El mismo análisis detalla que entre 2008 y 2010, los entrevistados que atienden únicamente a la versión electrónica de los diarios ascienden del 22,9\% al 32,1\%, y descienden más de 6 puntos los que tan sólo leen la prensa impresa, pasando de 13,5\% a 7,3\%. No obstante -sigue la fuente citada-, la mayoría de aquéllos leen ambas versiones $(54,8 \%)$, y muy pocos $(5,6 \%)$, los que no leen ninguna.

Este balance representa un filón imposible de obviar por parte de todo tipo de organizaciones que desean comunicar sus actividades a través de mensajes publicitarios: aunque los medios impresos están ahí, las inserciones en los digitales son asignatura obligada dentro de las estrategias que diseñan la presencia de la marca en los ámbitos mediáticos: quien desea informarse sobre cómo marcha la economía y la política, sobre sucesos destacados, o agenda cultural, recibirá con cierta atención impactos publicitarios que de algún modo tengan que ver con esos contenidos o encajen con sus preferencias personales.

\section{Alta especialización}

Podemos hablar de alta especialización y entenderlo fácilmente si observamos lo que ocurre en el sector editorial de revistas. Cada mes, en los quioscos, cientos de publicaciones especializadas en hobbies contentan a afanados seguidores en materias como la caza/pesca, las casas de muñecas, el montañismo, el surf, el género de la ciencia ficción, el modelismo naval, el bricolaje, o la botánica...son sólo piezas ilustrativas que nos llevan a nuestro asunto.

Al igual que estos lectores que no faltan a su cita al quiosco cada primera semana de mes -y que acaban suscribiéndose por comodidad-, la TV por Internet IPTV (Internet Protocol TV) enlata una serie de contenidos que sólo ven los usuarios realmente interesados. Se trata de un mecanismo extraordinario para "fidelizar" la audiencia/clientela de un emisor/productor o un conjunto de ellos.

David W Schumann, Andy Artis y Rachel Rivera (2001) remarcan la importancia de la fidelización como baza de rentabilidad publicitaria y aseguran que el intercambio de información entre consumidores y productores -quienes crean contenidos y programan- resulta vital para reforzar la relación que se establece luego entre el emisor del mensaje publicitario y el consumidor.

\section{IPTV en banda ancha}

Atendiendo a las aproximaciones teórico-prácticas de estos nuevos sistemas comunicativos, Internet Protocol Television (IPTV) se ha convertido en la denominación más común para los medios de distribución por subscripción de señales de televisión o vídeo usando conexiones de banda ancha (ADSL) sobre el protocolo IP.

Esta tecnología se aplica habitualmente junto con el servicio de conexión a Internet, proporcionado por un operador de banda ancha sobre la misma infraestructura pero con un ancho de banda reservado. Pero no se debe confundir el concepto de visualización de este tipo de TV pues lo más habitual es seguir contenidos bajo el mismo monitor de TV, no el monitor el ordenador. 


\section{Un concepto que parece difícil pero no lo es}

Existen algunas confusiones terminológicas, y algunos autores (Delgado y Fernández Quijada, 2007: 1) matizan que:

“(...) No se debe confundir la IPTV con la televisión por Internet. Respecto a ésta, la novedad y mayor virtud de la IPTV radica en el hecho de que el consumo se realiza desde el monitor de televisión, con todo lo que ello implica respecto a hábitos de consumo, falta de necesidad de una cultura técnica para su manejo, calidad de la imagen, etc".

Las reflexiones precedentes son claras: igual que el libro sobre papel podrá seguir conviviendo por mucho tiempo con el ebook, o el periódico, con el diario digital en Internet (circunstancia con una fecha de caducidad mucho más clara), la recepción de los mensajes vía monitor estándar de TV convivirá aún en Europa, durante mucho tiempo, con el consumo de imágenes y sonidos por otras vías (Internet en portátiles, productos varios en iPads, películas en mini reproductores DVD, y un largo etcétera).

La Fundación Telefónica [7], a través de su boletín "La Sociedad de la Información", [8] ha explicado de forma sencilla el funcionamiento del sistema, que tiene como principal protagonista a su marca Imagenio (otros operadores potentes en nuestro país son Orange TV, o Yatv (también de Orange, o France Telecom), entre otros:

“(...) a través del mando del televisor el espectador decide qué es lo que quiere ver y cómo lo quiere ver. (...) el nuevo sistema nos proporciona una gran diferencia ya que pasamos de una televisión con horarios y con contenidos predefinidos a un modelo de servicio que nos va a permitir personalizar la oferta a cada cliente, que verá lo que necesita en cada momento sin imposición de horarios".

\section{Vídeo-streaming}

IPTV ha sido desarrollado técnicamente basándose en el vídeo-streaming, que se define como la emisión de audio/vídeo por Internet mediante una corriente continua (sin interrupción). En palabras más sencillas, el individuo puede escuchar/ver productos audiovisuales en el momento que quiera y sin necesidad de tener que descargárselos previamente.

En nuestra televisión IP a la carta, el emisor de mensajes audiovisuales no emitirá sus contenidos esperando que el receptor se conecte, sino que los contenidos llegarán sólo cuando el cliente los demande. La clave está en la personalización del contenido para cada individuo. Esto permite el desarrollo del pay per view (ppv) o pao por evento (ppe) o el vídeo bajo demanda (vbd), fenómeno conocido en países anglosajones como video on demand (vod).

Gracias a todas estas facilidades, el telespectador de IP dispondrá de un aparato receptor conectado a su ordenador o a su televisión y a través de una herramienta-guía estará en disposición de seleccionar los contenidos que desea ver o almacenarlos en el receptor y de esta manera poder verlos tantas veces como desee.

Se trata de una oportunidad de negocio que está dando ingentes frutos a las grandes operadoras. Sáinz Macías (2007: 62) indica: 
"(...) todos los estudios de mercado reiteran la evolución hacia una "sociedad del ocio" y un aumento del gasto dentro de este campo. En este sentido, el servicio de televisión por IP abre grandes oportunidades de negocio a las operadoras para captar nuevas áreas del presupuesto familiar del cliente, pues, adicionalmente a las llamadas de voz y servicio de datos, cuyo margen es cada vez menor, IPTV permite a las operadoras acceder a nuevas líneas de negocio para atacar los gastos de entretenimiento y ocio familiar".

El éxito que está cosechando este nuevo medio que es el perfecto híbrido de tecnologías dentro del nuevo panorama de los TIC es evidente. Daniel Vicente (2007) trae a colación esta idea:

"La Televisión por IP está de moda. Las revistas especializadas informan asiduamente de lanzamientos de proyectos piloto y despliegues comerciales realizados por operadores de telecomunicaciones y de cable. La IPTV es fruto del proceso imparable de convergencia del audiovisual, la electrónica de consumo y las TIC".

Prado, Franquet, Ribers, Soto y Quijada (2007) aseguran que la fragua entre televisión y red de redes es una realidad que está multiplicando los interlocutores del mercado: usuarios, productores-emisores y anunciantes están conviviendo en un vanguardista contexto que cada día cambia o se reinventa:

"La hibridación televisión/Internet es una tendencia evidente, observada tanto en la producción y distribución como en el consumo de mensajes audiovisuales. La ofensiva comercial de distintos actores presentes en el mercado con sus ofertas de triple play acelera esta tendencia. Así pues, las posibilidades de tener un paquete disponible en el hogar de un único proveedor y con servicios de telefonía, televisión y acceso de banda ancha a Internet facilitan los nuevos consumos audiovisuales procedentes de fuentes diversas. En este proceso, las posibilidades interactivas de un medio complementan las capacidades audiovisuales del otro y viceversa".

En nuestro país, el incremento del consumo de imágenes y sonidos a través del sistema streaming es imparable. Según The Cocktail Analysis (2010), el consumo en streaming ascendió en España espectacularmente entre 2009 y 2010, "hasta el punto de que el $50 \%$ de los internautas dice haber utilizado esta forma de visionado (directo, sin descargas) para acceder a contenidos de su interés".

Otro dato revelador emitido por este informe añade que el consumo en streaming llega a una media de 6,5 horas a la semana, lo que nos advierte de hábitos que evidentemente son una diana certera para anunciantes.

\section{Más posibilidades publicitarias. Marketing de cercanía}

Los sistemas de televisión por Internet han tenido un gran éxito desde su implantación, y esto se ha traducido en la aparición de una nueva fórmula de "desembarco de estrategias" para publicistas y corporaciones.

Según algunos estudios recientes, (Los Santos Aransay, 2009) el sistema abre claras posibilidades competitivas:

“(...) las empresas que ofrecen servicios de Internet, han visto cómo IPTV les permite desplegar un nuevo conjunto de aplicaciones sobre la misma infraestructura, permitiendo rentabilizar más 
aún sus redes ya desplegadas, compitiendo contra otras opciones como la televisión digital terrestre y la televisión por satélite, para intentar ocupar el lugar dejado por la emisión analógica".

El boletín citado líneas atrás [9] señala que una de las ventajas claras de publicitarse según los parámetros del nuevo medio se concreta en que trata de un canal bidireccional donde los usuarios podrán determinar y seleccionar cuales son las áreas de interés sobre las que les gustaría recibir ofertas de publicidad, siendo así mucho más efectiva.

El usuario puede emplear entonces su televisor al mismo tiempo como un reproductor DVD interactivo y como pantalla multifunción en la que puede consultar Internet, comprar entradas, efectuar transacciones bancarias, leer los correos electrónicos de las cuentas vinculadas, y otras ventajas.

La interactividad en un sello de marca de la nueva televisión, y esto es un factor especialmente interesante para los anunciantes, que ven en sus destinatarios sujetos más proclives a recibir mensajes mucho más cercanos y personalizados.

Se trata de una situación 'mercadotécnica' nueva que algún analista a terminado de definir como "marketing de proximidad".

No cabe duda de que nos encontramos ante un reflejo más comercializable del "marketing viral", o sea del 'boca a boca' sobre algo que se extiende en las redes sociales y entre usuarios reenviados del correo electrónico.

Otro de los factores clave que propicia el uso simbiótico televisión-Internet es la combinación 'práctica' de contratación junto a otros servicios en el hogar. Concienciado de que tiene que pagar de igual forma, aunque evidentemente se beneficia de un conjunto de 'recursos de entretenimiento para casa', el cliente prefiere el pago de tarifa plana por varios componentes.

Al parecer, con datos incluidos en la aludida fuente The Cocktail Analysis, se nos informa que para el $46 \%$ de los individuos que tienen un abono a televisión de pago, el "paquetizado" de servicios (televisión + Internet + teléfono) ha sido el factor principal que motivó la contratación del mismo.

\section{Imagenio}

Imagenio [10] es una la plataforma IPTV que nace bajo el paraguas mediático del Grupo Telefónica, ahora Movistar, y que cuenta con un número importante de abonados en nuestro país.

Se trata de un sistema de televisión a la carta que le permite al usuario organizarse muy bien en casa para auto-diseñarse una programación -a medida de sus afinidades- con una máxima libertad en la selección de contenidos.

Aunque las opciones programáticas son muy generosas, existe una limitación que forma parte del propio negocio de Imagenio: cuando el usuario traspasa una serie de demandas debe indicarlo expresamente con el correspondiente incremento en la tarifa, aunque el suplemento se carga en la cuota que se pasa a final de mes a la cuenta corriente del abonado.

Imagenio ofrece un sistema técnico que se conecta al televisor y, gracias a un mando a distancia intuitivo podemos seleccionar los canales y opciones de contenido que nos brinda la plataforma. 
El mando incluye una botonera y cuatro opciones básicas codificadas en cuatro colores: verde (ver más), amarillo (abrir cupón), rojo (consíguelo) y azul (maximizar/minimizar ventana).

La estrategia publicitaria esencial de Imagenio se basa en atractivas promociones y ofertas de las que se puede beneficiar el consumidor. Algunas de ellas son solamente accesibles, curiosamente, si éste es capaz de ser "comercial" para la propia firma, animando a amigos, familiares o vecinos a contratar el servicio.

En el sistema podemos leer, por ejemplo, rótulos promocionales en los que se invita al abonado a captar nuevos clientes, acción que beneficia a quien lo consigue ganando precios exclusivos 0 "regalos especiales", como 4 películas gratis en el videoclub de Imagenio por cada nueva incorporación.

El potencial promocional de Movistar, potente en los ámbitos de sus medios de difusión y creatividad, utiliza hábiles combinatorias, presentadas atractivamente, que buscan en esencia mantener interesado al abonado con las ofertas nuevas que cada día puede sumar a los paquetes que de forma mecánica ya tiene contratados.

Las posibilidades de consumo de contenidos programáticos y paquetes adicionales de canales y/o espacios de contenido individuales (películas, documentales, retransmisiones deportivas, y otros) son múltiples. La plataforma puede ofrecer hasta 230 canales de vídeo/audio diferentes y más de 15 de audio.

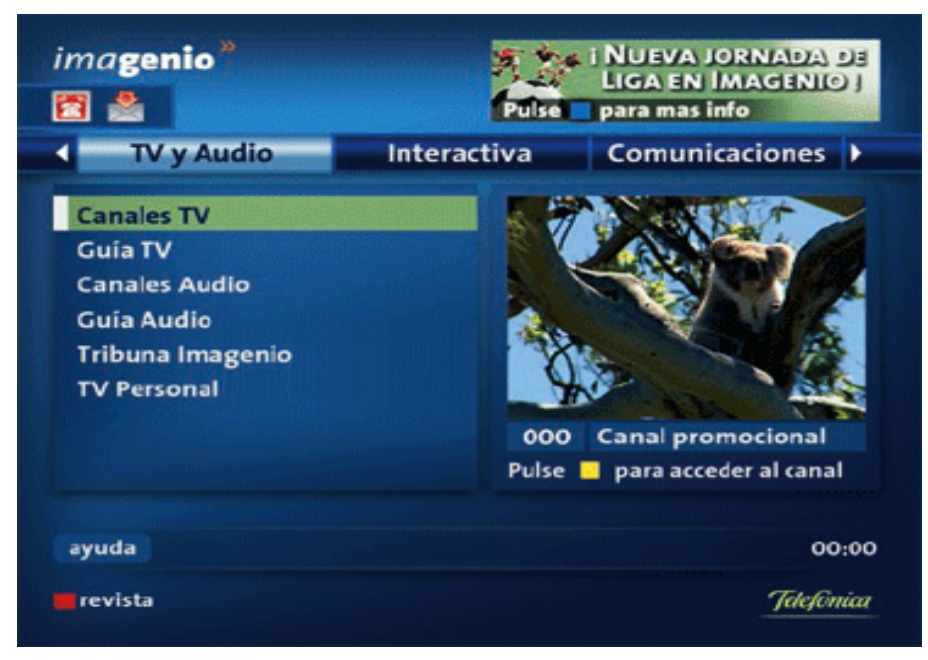

Figura 1. En la plantilla de apertura de Imagenio tenemos acceso a las opciones audiovisuales y de audio en exclusiva: canales de TV, Guía de TV, Canales Audio, Tribuna Imagenio (Espacios Deportivos) y Televisión Personal (Captura realizada el 17 de diciembre de 2010).

La paleta de formatos es sugestiva y voluminosa: desde conciertos en directo, documentales, películas, series, o sitcoms (comedias de situación), hasta reportajes sobre estilos de vida, espacios con consejos de salud, emisiones deportivas y campeonatos, practicum para hobbies, y otros muchos.

En simultáneo, el abanico temático comprende la satisfacción de gustos muy diversos: Baby TV [11] (un canal con programas específicos para niños de menos de tres años), Yacht and Sail 
(como su propio nombre indica, un marco de referencia para los amantes del mar y la navegación con ejemplos de embarcaciones, técnicas y demás aspectos), Canal Parlamento (emite desde hace años señal institucional del Parlamento y también ha emitido Canal Senado), The Poker Channel (para los incondicionales del juego de cartas), Art Channel (único canal temático en el mundo dedicado íntegramente a la difusión del arte en todas sus variantes expresivas), Unitel Classica (excelente legado audiovisual para los aficionados a la escucha de recitales de música clásica) y un largo listado.

Para que el abonado se sienta más cómodo, en la contratación de espacios de contenido, se cuenta con un letrero electrónico parcelado que aparece en la pantalla al pulsar "Televisión a la Carta" y permite elegir las tarifas reales que más pueden interesar en un momento dado.

Los pases Imagenio de 24 horas para series cortas y largas oscilan entre 0,99 y 2,59 euros, y la Zona Suscripción mensual asciende a 4 euros. Todo depende de la concentración seleccionada por cada abonado.

Asimismo, en el diseño azul segmentado en cajas y pestañas se ubican espacios publicitarios (banners) que normalmente ocupan posición en las zonas derecha y/o superior del espectador.

En estos marcos se rotan reclamos publicitarios con tráileres o teasers [12] de películas, carteles de films, secuencias de series o documentales, y demás sugerencias del propio menú personalizado.

En la sección de "Televisión a la Carta" se insertan spots publicitarios que contratan anunciantes que ven en Imagenio un contexto propicio de impacto de mensaje debido a la segmentación de la audiencia.

Algunos de estos ejemplos comerciales se dan a conocer en cooperación con el portal de venta online y telefónica www.latiendaencasa.com.

En muchos casos, los artículos a la venta (online o por teléfono) van dirigidos a un público de ambos sexos de clase media alta, de mediana edad, el perfil que normalmente demanda Imagenio en casa, personas que tienen tiempo para consumir televisión y, aunque la mensualidad estándar es bastante asequible, tienen un bolsillo holgado para contratar paquetes básicos y contenidos adicionales abundantes sin mayores preocupaciones.

Por este motivo, algunos de los productos que se publicitan se dirigen a un receptor en los perfiles mencionados: un jamón ibérico y un portátil HP con maletín.

Imagenio incorpora en su plataforma una revista interactiva en la que, además de actualizar la presentación de noticias y autopromociones, brinda a los abonados la oportunidad de comentar aspectos que pueden interesar mucho tanto a programadores (los que eligen qué contenidos ofrecer) como a anunciantes (que aprovechan la parrilla disponible y la 'temperatura' de los mensajes de los clientes en torno a dónde van las tendencias y los gustos).

Según una noticia del boletín "Grupo ADL Zone" (11 de noviembre de 2010) la plataforma IPTV de Movistar sigue aumentando sus cifras, y ya cuenta con 773.000 abonados a último día de septiembre de 2010; con ello podríamos intuir que el sistema ya tiene unos 800.000 seguidores a día de hoy. 
En el tercer trimestre de 2009 se lanzó Gol TV y esta estrategia impulsó notoriamente la actividad comercial en dicho período, captando a muchos nuevos abonados.

\section{Yatv}

Yatv es una plataforma IPTV de televisión perteneciente a Yacom, cuya propietaria original, Deutsche Telekom, la vendió al Grupo Orange en 2007. Orange España (marca comercial de France Télécom España, S.A.) es una compañía de telecomunicaciones perteneciente al grupo France Télécom. Este operador agrupa al operador de telefonía móvil adquirido en julio de 2005 (anteriormente Amena, propiedad de Auna) con los otros tres negocios que France Télécom ya tenía en España: telefonía fija para empresas (Uni2), red de datos internacionales para corporaciones (Equant) y acceso a Internet y telefonía para particulares (Wanadoo). La plataforma emplea la tecnología desarrollada por Alcatel sobre la plataforma de IPTV de Microsoft TV.

Yatv se concibe como un soporte de entretenimiento en el que se integran canales de ocio (deportes, cine, moda, música, etc.) dirigidos a un sector de población mayoritariamente joven y de mediana edad (entre 18 y 45 años), segmento que coincide con el máximo nivel de demanda y uso de telefonía móvil y otros productos del Grupo Orange.

La página web de la plataforma www.yatv.com permite la visualización de vídeos, spots, clips musicales, películas, publirreportajes y promociones, y el consumo de piezas audiovisuales a sus abonados en tiempo real una vez han formalizados sus pagos/ suscripciones correspondientes.

Asimismo, algunos de los espacios pueden ser consumidos libremente por internautas que no son abonados al servicio.

El diseño de la plataforma responde a cánones que se asemejan a la línea cromática y tipográfica que presenta su catálogo comercial: una combinación entre fondos negros y tipos de color naranja intenso.

El interfaz es intuitivo y facilita la atención del espectador en la pantalla evitando molestas distracciones (ausencia total de ventanas emergentes o pop-ups, banners con movimiento, etc.).

En la botonera izquierda se presentan cuatro enlaces a "Canales de los usuarios", "Canales Orange", "Canales de TV", y "Televisión a la Carta". En la botonera superior figura un enlace a "Mis canales".

En la botonera inferior encontramos tres botones, play-pause, avance, y retroceso, además de control de sonido, control de la duración de la pieza, mando para solicitar pantalla completa, un descriptor que resume en muy pocas palabras el contenido que tenemos delante y un botón de "enviar a un amigo" que deriva a una ventana en la que se escribe el correo electrónico de la persona a la que se desea enviar el enlace y un campo para escribir un mensaje.

Finalmente, en el grupo de botones del margen superior derecho encontramos un formulario de registro, un botón para efectuar la conexión con petición de usuario y contraseña, una opción de suscripción para recibir el boletín electrónico de promociones perteneciente al Grupo Orange, un enlace a "Nosotros" en el que se explican las Condiciones del Servicio, incluyendo la Ley de Protección de Datos y las Condiciones Generales del Servicio de Yatv, y un pequeño motor de búsqueda de información interna que orienta al internauta sobre contenidos disponibles. Por 
ejemplo, si tecleamos la palabra "enrique" aparece la selección de un canal musical y 21 clips musicales del cantante Enrique Iglesias.

Si dejamos de mover el ratón y va a comenzar un programa o pieza audiovisual, las botoneras desaparecen para mejorar la visualización de los contenidos en todo lo ancho de la pantalla del ordenador y/o televisor si el usuario posee conexión de Internet vinculada a su equipo de televisión.

\section{Mensajes publicitarios en Yatv}

Las inserciones publicitarias de esta plataforma, dirigidas tanto a los abonados como a los no abonados que pueden ver ciertos contenidos, se clasifican básicamente en cinco variantes:

a) Los anuncios de productos externos vinculados a los gustos de los usuarios que consumen habitualmente contenidos de Yatv.

b) Los anuncios de auto-promoción que informan sobre las ofertas y los lanzamientos-estrenos que se pueden ver próximamente en la plataforma.

c) Publirreportajes que contienen entrevistas, personas anónimas que se refieren a marcas, o famosos que patrocinan o dan imagen a marcas o películas (modelos, actores, actrices, etc.).

d) Trailers de películas que con toda probabilidad se podrán ver a corto-medio plazo en la plataforma.

e) Trailers de videojuegos cuyas firmas utilizan el soporte de Yatv para llegar a potenciales compradores.

El grupo Orange incluye, en su estrategia de publicidad, una técnica relativamente nueva denominada en inglés behavioral targeting o behavioural targeting, empleada para aumentar la efectividad de las campañas online y que usa información extraída de los hábitos de consumo individual de cada destinatario en la red.

La técnica toma como base la información que cada persona registra en su histórico de clicks, sus comportamientos y afinidades, y en definitiva, las páginas que visita y las búsquedas que normalmente efectúa.

De este modo, es mucho más sencillo planificar inserciones publicitarias que van mucho más acordes a las tendencias y necesidades del usuario. Este tipo de 'marketing de comportamiento', como también se le ha llamado, puede combinarse igualmente con patrones o indicadores sobre el entorno geográfico, demográfico y social del individuo.

Obviamente, esta metodología publicitaria se vincula íntimamente al aprovechamiento comercial de una audiencia segmentada y perfectamente definida en gustos de consumo por edades, comportamientos y otros parámetros muy determinados.

Estos planteamientos de marketing en la red ya han sido ensayados con éxito por algunas grandes compañías de venta por Internet, como Amazon, el gigante de la venta de libros que ha 
multiplicado su negocio con un sinfín de productos (CDs, juguetes, etc.) y que ofrece al internauta, en tiempo real (o en su siguiente búsqueda), productos afines a las últimos artículos buscados.

El consumo de contenidos audiovisuales, por su propia naturaleza de parcelación multicanal, va dibujándose conforme a un panorama diversificado en el que se van conformando targets muy nítidos con los que el cliente puede asegurar una mayor garantía de éxito respecto a su posicionamiento.

El Grupo Orange, en la información online disponible, incluye en su pestaña sobre "Publicidad" un apartado específico que, bajo el encabezado "Descubre la segmentación con Orange Advertising Network, explica los beneficios del behavioral targeting para los anunciantes". [13]

Esta información aclara que "seleccionamos sólo a los usuarios afines en cada categoría" y que "gracias al seguimiento de la actividad del usuario en los diferentes apartados de nuestra red conseguimos mostrarle publicidad relacionada con sus últimos hábitos de navegación, esté donde esté".

Hasta hace pocos años, el rastreo de los hábitos de consumo de los usuarios venía muy coartado por el resultado de encuestas que no siempre registraban con exactitud una serie de datos que, finalmente, iban a parar a los departamentos de marketing de las empresas ordenantes, quedando obsoletos en poco tiempo.

Los informes dependían del ratio de las encuestas y de la verosimilitud de las respuestas, muy condicionadas por la honradez de las personas, sus códigos morales en ocasiones, y el condicionamiento psicológico de los individuos, entre otras variables.

La reunión de un conjunto de clicks por parte de un receptor queda registrada por el sistema, convirtiéndose en un retrato robot perfecto que puede marcar desde las necesidades básicas de consumo (alimentación, ropa, ciertos medicamentos) hasta las exploraciones más minuciosas, búsquedas para investigaciones o libros si el internauta es docente o escritor, comparaciones de ofertas y artículos rebajados para hacer un regalo, elementos o herramientas para satisfacer algún hobby, y un largo etcétera.

Yatv ha basado su planteamiento comercial en un acercamiento a los clientes que hacen click sobre los canales que mejor comparten sus gustos personales, contenidos muy compenetrados con sus aficiones o actividades en el tiempo libre.

Así, las últimas tendencias en motor, moda, estrenos cinematográficos, videojuegos, artículos deportivos, músicas temáticas (rock, pop, hip hop), género buzz (contenidos para públicos jóvenes basados en la animación de ciencia ficción y manga, deportes extremos, videoclips, etc.) y otros referentes, construyen un tejido 'polifacético' donde se multiplican las posibilidades de insertar anuncios adaptados.

El citado informe recoge una serie de ratios por perfiles que llaman la atención y pueden orientar con mucha precisión al anunciante. En el momento en que estos datos fueron recogidos se estimaron las siguientes cuantificaciones de clientes por sectores de afinidad, y en mayor proporción:

-Música (5.574.816 clientes).

-Móviles (2.853.044 clientes). 
-Dating (2.168.015 clientes).

-Gadgets, agendas, cámaras, tecnología (1.835.202 clientes).

-Seguros (1.775.741 clientes).

-Finanzas (1.214.527 clientes).

-Coches (1.010.134 clientes).

-Cultura (921.888 clientes).

-Autónomos (769.171 clientes).

-Cine (549.402 clientes).

-Belleza e Higiene (535.992 clientes).

A continuación se comentan y analizan varios spots de Yatv, según una consulta pormenorizada que hemos realizado entrando repetidas veces en canales y opciones de contenido:

\subsection{Anuncios de apertura}

Los anuncios de apertura que Yatv va incluyendo en rotación, nada más conectarnos a su sitio web, tienen básicamente dos grupos de consumidores: un público joven (al que se dirigen anuncios de tarifas especiales de Orange móviles, profilácticos Control, y otros) y un conjunto de telespectadores de más amplio espectro de edad, más generalista, (un target de familia de clase media de entre 30 y 55 años) que recibe mensajes como Gas Natural Fenosa o Adif Alta Velocidad Madrid-Valencia, entre otras firmas.

Con esta premisa se puede intuir el enfoque publicitario que marcan los anunciantes de esta plataforma de televisión IPTV: captar la atención de personas de edades distintas con diversas potencialidades económicas y necesidades.

De este modo se pretende garantizar un éxito de enganche entre audiencias diversificadas, bien en proceso de abonarse, o ya abonadas. La ambientación de un segmento y otro, en definitiva, el 'concepto 'plasmado a través de lo que vemos y cómo lo vemos ( $\mathrm{y}$ en este punto influyen el trabajo de los actores, el guión, los diálogos expuestos, la música o jingle elegidos, la escenografía, y los efectos especiales de posproducción) transmite las siguientes ideas:

-Calor de hogar.

-Sensación de libertad.

- Tener amigos.

- Vivir con alegría lo cotidiano.

-Comprometerse con la solidaridad.

-Apoyarnos en lo familiar.

-Poder hablar con quien queramos con tarifas muy ajustadas.

- Viajar y comprar dentro de nuestro país a precios muy razonables.

Todas ellas transmiten cercanía y emigran de inmediato a un territorio de nuestro cerebro que nos lleva al placer y al sentimiento de bienestar. El hecho de recibir estos mensajes a través de la plataforma de Yatv nos ofrece tres ventajas respecto al visionado estándar de otros canales de televisión TDT:

-La apertura de la página web permite la rotación de anuncios que varían respecto a los días sucesivos en los que nos conectamos. 


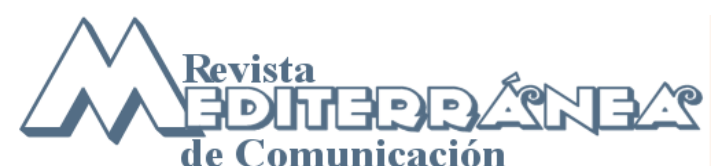

ISSN 1989-872X - Año2 (2011), pp. 72-102

-Podemos consumir estos anuncios las veces que queramos, avanzando, parando o retrocediendo.

-Incluso podemos prescindir de los mismos pinchando en el botón "saltar publicidad" sin necesidad de emigrar a otro canal o salirnos de la red.

\section{1.a. "Ahorro Hipercor"}

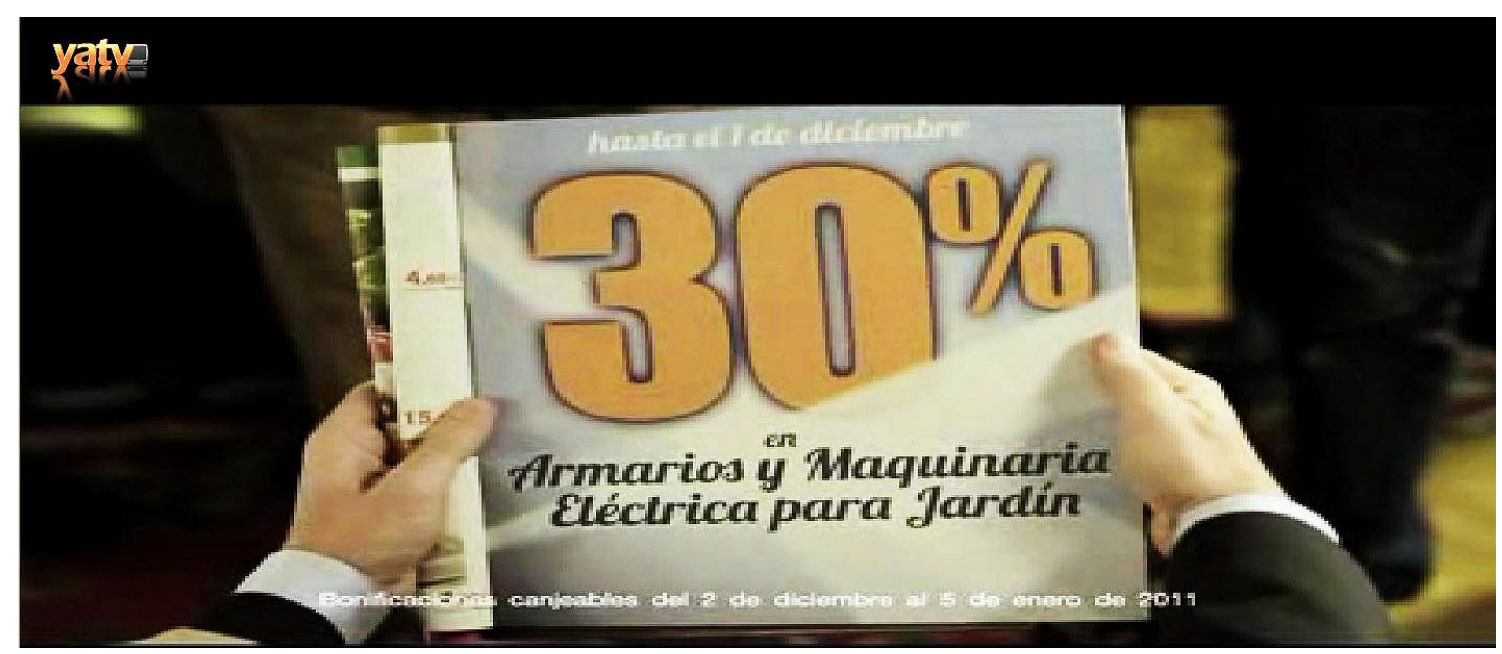

Figura 2. Una de las ofertas que se dan a conocer en el spot del 30 Aniversario de Hipercor (captura realizada el 30 de noviembre de 2010).

El anuncio que coincide con el 30 Aniversario de la firma Hipercor arranca con la llegada de un hombre a su hogar después del trabajo, donde le espera su mujer, que le ha organizado una fiesta sorpresa junto a un grupo de amigos y familiares. El hombre, que no sospecha semejante recibimiento, pregunta "¿Aquí qué se celebra? Y su mujer responde "Se celebra el Día Mundial del Ahorro, el Ahorro de Hipercor".

Con este diálogo da comienzo una presentación donde el desarrollo de esa fiesta hogareña invita al espectador a conocer las distintas ofertas de descuento en productos que brinda la marca en su aniversario.

El destinatario del spot responde a un criterio generalista, es decir, tiene un perfil amplio de ambos sexos con un segmento de edad aproximado entre los 30 y los 55 años.

En los letreros que se muestran a cámara se especifican ofertas de varios productos como armarios, maquinaria eléctrica para jardín (30\% de descuento), un $70 \%$ de descuento en la venta de segundas unidades dentro de un amplio surtido de artículos, una lavadora Samsung a 299 euros, y un televisor de plasma Samsung de 42 pulgadas. 
A tenor del tipo de productos que se ofrecen, podemos identificarlos con audiencias (de distintas edades) muy proclives a desarrollar actividades de bricolaje, jardinería, tareas de hogar y visionado de películas en amplias pantallas.

El frame de cierre, o mensaje de claim, [14], que reza "30 Aniversario de Hipercor, ¡Celebra el ahorro!", vuelve a recordarnos que acudamos a Hipercor mientras explosionan fuegos artificiales en un cielo nocturno. Los publicistas o creativos nos envían un mensaje subliminal con fuegos artificiales alternativos de color rosa o azul, símbolos de lo masculino y lo femenino.

Esta fórmula fue empleada por primera vez con éxito en el anuncio de una conocida marca de preservativos mientras se hacía una alegoría del éxtasis sexual mediante estallidos de fuegos artificiales rosas y azules.

\section{1.b. Cortometraje "Pequeño Palacio", de la Escuela TAl}

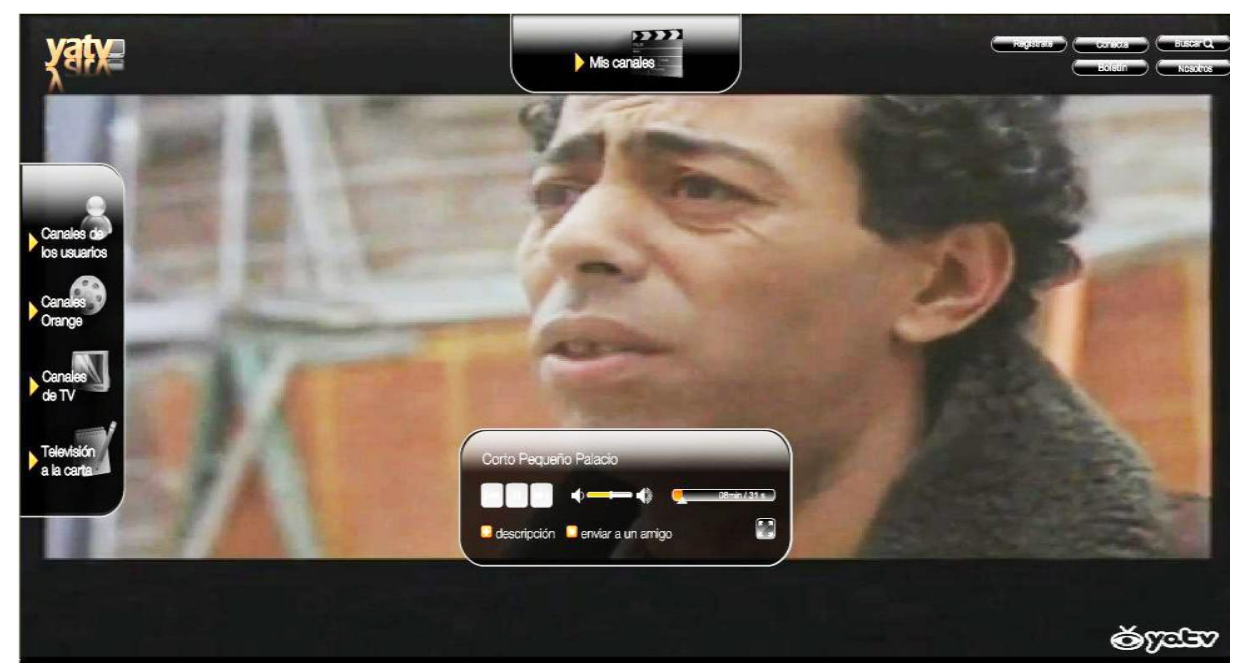

Figura 3. Fotograma del corto (captura realizada el 30 de noviembre de 2010).

Tras el spot de apertura se nos proyecta en pantalla un cortometraje realizado por alumnos de la Escuela Superior de Artes y Espectáculos de Madrid (TAI), lo cual podemos entender como un método de promocionar los planes formativos de esta escuela privada de enseñanzas audiovisuales.

Sin duda se trata de una original opción de hacer publicidad para usuarios aficionados al cine que ruedan cortos en su tiempo libre o para estudiantes, $y$, también, una referencia para los amantes del cine de autor.

Teniendo en cuenta los -hasta hace pocos años- limitados canales de difusión de los cortometrajes (antes de la llegada de Internet tan sólo existían algunas televisiones y festivales que apostaban por exhibir este tipo de modestas producciones), el propio formato puede ser un reclamo atractivo para enganchar a jóvenes que consumen Yatv y que en estos momentos están decidiendo qué estudios universitarios emprender. TAI se anuncia como una opción práctica que muestra en pantalla ejemplos palpables (cortometrajes) que funcionan como 'gancho' para futuros estudiantes. 
En este caso se nos exhibe el corto "Pequeño Palacio", dirigido por David Cordero y protagonizado por Farid Fatmi y Úrsula Murayama. La pieza es una reflexión en torno a la inmigración y las dificultades de integración laboral del colectivo. Un trabajador extranjero acude cada mañana a una obra para tratar de que le den oportunidad de trabajar. Mientras tanto su novia, algo frívola pues se irá con el primero que le garantice un futuro, espera que algún milagro se produzca y se puedan casar. Aunque se prima un cuidado sentido del humor, la obra ironiza con el problema del paro y nos inyecta la necesidad de criticar el sistema, sobre todo por la xenofobia aún imperante en la sociedad.

\subsection{Anuncios por canales}

La plataforma de Yatv tiene básicamente cuatro opciones de grupos de canales, dos primeros, "Canales Usuarios" y "Canales Orange", visibles para los no abonados a través de la web, y dos segundos, "Canales de TV" y "Televisión a la Carta" de acceso restringido para abonados.

En el bloque de "Canales Usuarios" tenemos un abanico extenso de posibilidades de consumo de contenidos, entre otros, "Mis Vídeos", "Fox", "Canal Adulto", "Música y Cine en Yatv", "The Ventures (selección reyes surf)" y

"Los Pattex".

Esta zona es susceptible de aceptar la inserción de contenidos enviados por los propios usuarios, un modo de construcción de contenidos más social y comunitario, más en línea con las plataformas online tipo 'foros' que modelan y analizan un tipo de discusión en torno a un tema.

En este conjunto de opciones, se insertan varias opciones publicitarias que abarcan distintos segmentos de audiencias según gustos y edades, centrándose mayoritariamente en un público joven, gran consumidor de productos relacionados con la música pop-rock y videojuegos.

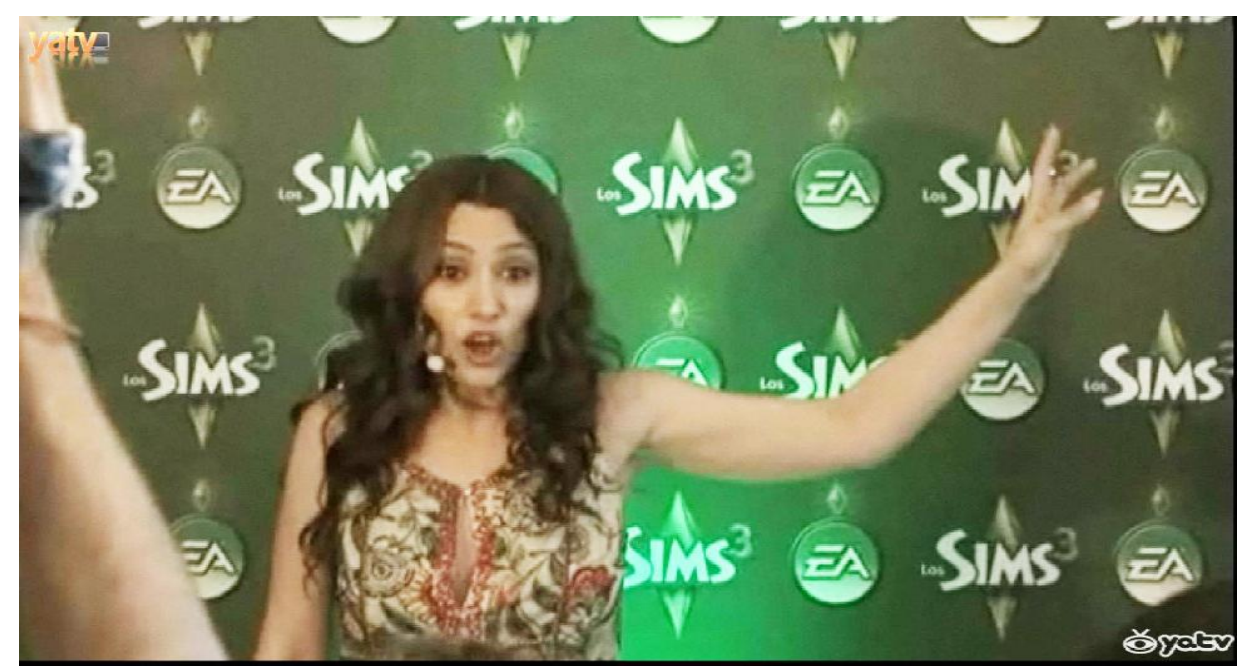

Figura 4. instante del acto de presentación del videojuego Los Sims 3, a cargo de la actriz Natalia Verbeke (captura realizada el 3 de diciembre de 2010). 
Uno de los spots que aparecen, en forma de videorreportaje en directo, es la presentación de la parte 3 de Los Sims, un exitoso videojuego social que ha revolucionado las temáticas en el mercado. Ya no es tanta la competitividad deportiva, los afanes aventureros por los nuevos descubrimientos geográficos o las veleidades bélicas. Ahora debemos enfrentar nuestra imaginación al nuevo reto de configurar el destino de nuestros protagonistas, definiendo sus posibilidades de conocer gente, sus alternativas al ocio, sus estilos de vestimenta o look personal, y otros retos de la vida laboral y cotidiana.

\subsection{Canales Orange}

El bloque de Canales Orange atiende las apetencias de consumo de muchos tipos de individuos, de ambos sexos, desde los interesados en el deporte de competición, o el motor, a los cinéfilos empedernidos, desde los seguidores de la última moda hasta los fans de los nuevos grupos de música.

Todo cabe en este paquete abierto también parcialmente a los no abonados, y por ello, los contenidos multidisciplinares aceptan variados spots vinculantes respecto a esos temas afines.

Veamos cómo muchos ejemplos publicitarios se benefician de su posicionamiento entre audiencias segmentadas para cada canal.

En el Canal Deportes nos encontramos varios tipos de reclamos publicitarios que rotan según vamos refrescando la página, desde equipamiento diverso para actividades que potencian el ejercicio físico (bicicleta de montaña, y otras) hasta presentaciones y videorreportajes, en los últimos meses, muy centrados en la promoción posterior de "La Roja" como Campeona del Mundo.

En este terreno, nos encontramos clips de homenajes a jugadores de la Selección, de forma individual o grupal, momentos de la exposición de la Copa del Mundo en distintos foros y enclaves del territorio nacional, y, cómo no, escaparates de venta de artículos de merchandising alegóricos del equipo de fútbol; en este sentido ocupa un puesto estelar la venta de camisetas y equipajes con los emblemas de "La Roja" que enganchan a públicos de todas las edades unidos por la afición común del fútbol.

Otra de las grandes apuestas publicitarias de la plataforma es la que converge con el público femenino en muchos temas de interés, especialmente relacionados con el mundo de la moda (pases de moda, entrevistas, reportajes sobre diseñadores y estilistas) belleza-estética (maquillaje, peluquería, tratamientos) y consejos de salud (hábitos alimenticios, protección solar), entre otros. La presencia de estrellas de cine, actrices y modelos en los espacios publicitarios del Canal Mujer es constante.

Nombres conocidos del panorama nacional e internacional dan vida a numerosos publirreportajes para grandes firmas de moda como Victoria's Secret, Mango (se nos muestra una entrevista con la actriz Scarlett Johansson), y protagonizan reportajes fotográficos y entrevistas en revistas del sector: Elsa Pataky, Paz Vega y Mónica Cruz para Elle, Megan Fox para Rolling Stone, Blanca Romero para FHM, y Dayana Mendoza para Maxim, entre otras. 


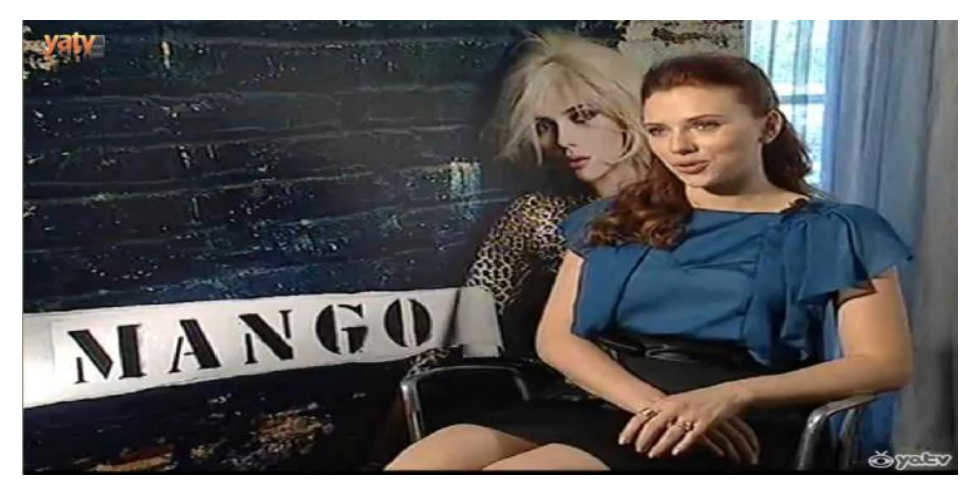

Figura 5. La actriz y modelo Scarlett Johansson concede una entrevista mientras posa con prendas de Mango (captura realizada el 17 de noviembre de 2010).

El paso constante de figuras de Hollywood se refuerza aún más en el Canal Entrevistas, un modo de promocionar las películas de estreno e incentivar la visita a los cines.

Esta sección que renueva sus contenidos intercalando trailers y teasers con entrevistas a los actores que encabezan los repartos de los estrenos aludidos.

A medida que se van lanzando nuevas premieres van quedando atrás promociones de títulos anteriores.

Así, Russell Crowe nos habla de su Robin Hood, Tom Cruise y Cameron Díaz saludan a sus fans en las localizaciones sevillanas de la película Noche y Día (durante su making off), y Sam Worthington comenta algunos detalles en el set de Furia de Titanes.

Aunque conscientes de cómo anda el mercado respecto a la competencia desleal y las descargas ilegales a través de la red, las grandes discográficas siguen tratando de captar la atención de potenciales compradores de CDs y de públicos que acudan a los conciertos donde se presentan nuevos álbumes.

Plataformas online y televisiones IPTV que dispensen contenidos muy en conexión con los jóvenes interesados en los nuevos solistas y bandas de pop-rock son idóneas para colocar clips y reportajes o entrevistas sobre un artista y grupo.

Yatv cuenta con varios canales de música como Live y, también, un canal especializado como Bustamante UDLN, un original encuentro del cantante cántabro donde explica en varias entrevistas cómo empezó en el mundo de la música, cómo ha grabado algunos videoclips y otras puestas en escena donde sus melodías y su forma de trabajar se expresan desde variadas facetas.

Finalmente, otro de los sectores que consideramos clave en el panorama publicitario de esta plataforma IPTV es el de la automoción.

Las posibilidades de muestreo son múltiples y diversas pues algunos canales como Supermotor TV, o Autocity, emiten frecuentemente publirreportajes con lanzamientos de nuevos modelos, exposiciones y pruebas en carreteras y calles, spots, making off sobre rodajes de spots, reportajes 
sobre mecánica y características técnicas de los automóviles, entre otros asuntos que sin duda mueven los resortes de interés del futuro comprador y aficionado.

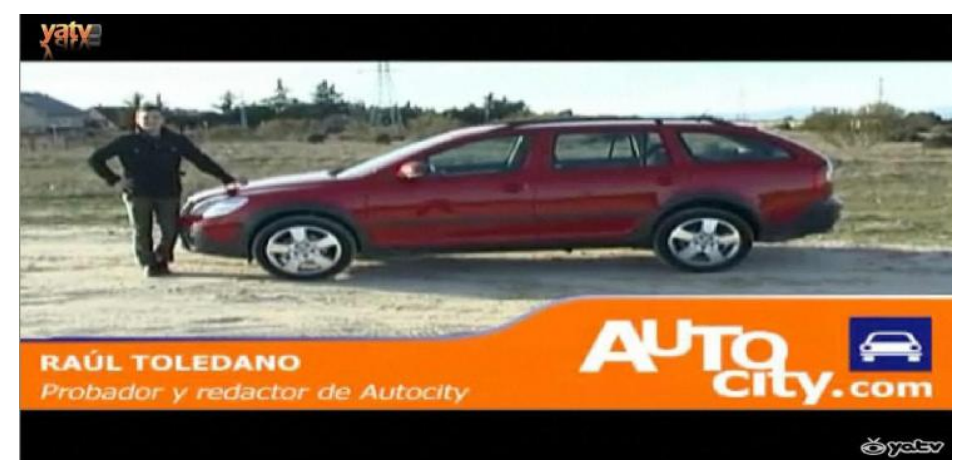

Figura 6. Un redactor del Canal Autocity comenta in situ las peculiaridades técnicas y de confort de un nuevo automóvil.

En el Canal Autocity, el propio redactor o periodista comenta en tiempo real cómo funciona un determinado modelo probándolo delante de la cámara.

Es un método muy práctico que vincula al futuro conductor de ese vehículo, familiarizándolo con los mandos y funciones del coche desde el puesto del conductor.

\section{Conclusiones}

Según hemos visto a lo largo de este artículo, durante los últimos años se ha producido una metamorfosis en la rentabilización de los mensajes comerciales-publicitarios gracias a una evolución en la forma de percibir los contenidos.

En el novedoso espectro mediático conviven -con inesperadas sinergias- el discurso televisivo, con la propia rapidez de los mensajes y las múltiples opciones de elección que brinda Internet, y esto ha marcado un antes y un después en la forma de enfocar las estrategias de comunicación.

Hoy por hoy, y en el escenario al que hemos hecho referencia, muchas cosas han cambiado: desde los diseños de los anuncios, hasta el desarrollo de las campañas publicitarias, pasando evidentemente por unas planificaciones de medios (la decisión de cuándo y en qué medios invierte el anunciante) que intensifican porcentualmente la presencia de la marca en demandadas plataformas digitales o en escaparates de audiencia segmentada que combinan el discurso televisual con Internet, como la IPTV.

No obstante, antes de concluir deberíamos dedicar un espacio a la reflexión.

Si bien el consumo de televisión generalista sigue constituyendo el 'buque insignia' masivo que tira del grueso de la inversión publicitaria en medios, muy pronto veremos cambios sustanciales, y la televisión concebida como caja electrónica de nuestro espacio social íntimo-familiar va a ir pasando a un plano mucho más secundario.

Lo que nos dicen los estadistas es nítido y no puede ser puesto en duda: la movilidad de las personas, el acceso a la tecnología y a los dispositivos móviles que permiten conexión a la red, la 
gratuidad de gran parte de los servicios, incluyendo la posibilidad de innumerables descargas de productos audiovisuales, y otros factores, son condicionantes que irán desplazando, poco a poco, los hábitos de consumo tradicionales.

Internet es el presente y el futuro, y esto lo saben muy bien los publicistas. El nuevo medio está desplazando a un conjunto segmentado de audiencias que ahora demandan la inmediatez y la libertad de elección/expresión (los contenidos de participación online tienen un gran peso) en contra del esquema arcaico de sentarse en el sofá y "tragarse" lo que sea (aunque el zapping sea un sano ejercicio practicado desde hace años).

La IPTV, en sus modalidades de pago, tiene una desventaja respecto al acceso directo a Internet o a la propia TDT (Televisión Digital Terrestre): el simple hecho de tener que abonar un canon para ver determinados contenidos es contraproducente. Como se sabe, muchos de los programas pueden ser de dominio público tratándose, por ejemplo, de series o películas, no tanto directos deportivos.

En el contexto de la actual crisis económica, el ahorro afecta en gran medida al sector del ocio y, debido a ello, el bolsillo de muchos se resiste a este tipo de compromisos mensuales que se cargan en las cuentas corrientes.

Al hilo de esta razón, la porción de la tarta publicitaria correspondiente a los consumidores de IPTV ha de ser estudiada con sumo cuidado por parte de los potenciales inversores: una información detallada hasta lo indecible sobre los perfiles de consumo (teniéndose en cuenta que los sectores poblacionales que contratan Imagenio, por ejemplo, tienen un nivel adquisitivo medioalto), deberían valorar todo tipo de cuestiones como hábitos de vida y alimentación, horarios de entradas y salidas, gustos, hobbies, artículos que se adquieren con frecuencia y otros parámetros muy útiles para los anunciantes.

Es cierto también que las plataformas que aquí hemos citado (Imagenio, Yatv) no se autopublicitan demasiado, ni en medios convencionales como la prensa, o la televisión generalista, ni en otros soportes externos como vallas. Estas plataformas prefieren promocionarse en los puntos de venta que se asocian generalmente a los sistemas de telefonía más cercanos a la propia marca: los centros Movistar para Imagenio, y los de Orange para Yatv.

Esto nos ratifica que la misma marca confía en personas que también contratan a la misma empresa para satisfacer sus demandas de telefonía (fija o móvil), recibiendo los impactos publicitarios de las correspondientes opciones de IPTV en las propias tiendas o comercios de venta de teléfonos móviles y productos afines.

Y otro factor que resta efectividad a la evolución a la propia tecnología de la IPTV y la televisión por Internet es que requieren de una serie de protocolos tecnológicos (cobertura, cableado, etc.) que no siempre pueden alcanzar determinadas zonas no urbanas, excluyendo porciones de audiencia que también podrían interesar a los responsables de publicidad de ciertas marcas.

En este sentido, sería deseable que el espíritu comercial de captación de nuevos usuarios, una vez sorteadas ciertas dificultades técnicas, fuera menos "urbanita" y más integrador.

Con todo, el análisis propuesto líneas atrás nos ha llevado por último a cuantificar un conjunto de aportaciones que se deducen del nuevo panorama audiovisual publicitario vinculado a la IPTV y a los ejemplos que hemos comentado. 
Veamos estos planteamientos conclusivos:

a) Cambio de Espectro en los espacios de contenido: Con la introducción de las plataformas IPTV, la propia naturaleza del mensaje audiovisual ha cambiado a enorme velocidad. Esta circunstancia está motivando que los anunciantes, en connivencia con emisores/publicistas diseñen un nuevo espectro de contenidos mucho más segmentados y especializados, más cercanos para públicos bien delimitados y mucho más homogéneos que los habituales de la televisión convencional entendida como como "mass media".

b) Mayor interactividad: Las televisiones a la carta propician una notable interactividad pues el usuario se implica con el sistema auto-diseñando su propia programación.

c) Mayor participación del usuario en los contenidos: No todo queda ya a expensas del autor o los programadores. Gracias a los distintos mecanismos que permiten garantizar la presencia de feedback por parte del consumidor de la plataforma (sugerencias, foros, chats, emails y la revista de Imagenio) se produce una mayor implicación de los usuarios. Con sus comentarios y sugerencias, hacen "opinión" construyendo diseños aún más adaptados a sus demandas, todo lo cual deviene en una información privilegiada para los estrategas de la programación, los publicistas y los anunciantes interesados en el nuevo formato.

d) A mayor segmentación, mayor beneficio: La segmentación permite un gran beneficio económico para el anunciante, quien advierte de las nuevas posibilidades de mercado y la inmediatez del mensaje. La importante presencia publicitaria (un alto porcentaje de anuncios), sobre todo en Yatv, concluye el interés de distintas firmas que apuestan por la IPTV para darse a conocer. Algunos de los ejemplos estudiados en este artículo advierten de la diana segmentada de ciertas audiencias: El spot de "Ahorro Hipercor" dispara sus sugerencias de compra a consumidores de hábitos bien delimitados, desde los proclives a llevar a cabo actividades de bricolaje o jardinería, hasta los entusiastas del cine que se interesan por las cómodas pantallas de plasma.

e) Mensajes en múltiple formato: El anunciante puede descubrir en la IPTV diversas fórmulas de inserción de anuncios, desde los clásicos spots, hasta los publirreportajes, banners asociados al diseño de la presentación web y product placement, con emplazamiento de producto en el propio discurso programático.

f) Perfiles de edad diversos: Los contenidos de Yatv se dirigen a un sector de población mayoritariamente joven y de mediana edad (entre 18 y 45 años), segmento que coincide con el máximo nivel de demanda y uso de telefonía móvil y otros productos del Grupo Orange. Yatv presenta algunas excepciones, sobre todo anuncios de apertura que se enfocan hacia potenciales destinatarios que abarcan un abanico de edades más extenso. Imagenio tiene como receptores a grupos generacionales diversos (las opciones programáticas van desde películas de animación hasta cine para mayores de 18 años), aunque quienes se abonan responden a un perfil socioeconómico más alto.

g) Variación en los poderes adquisitivos: Según se ha podido observar, en Imagenio, muchos de los artículos a la venta van dirigidos a un público de ambos sexos de clase media alta, de mediana edad, un perfil que normalmente demanda Imagenio en casa, personas que tienen tiempo para consumir televisión y tienen un poder adquisitivo holgado para contratar paquetes básicos y contenidos adicionales. En Yatv, sin embargo, muchos de los mensajes se focalizan a 
abonados pero también a un número elevado de usuarios jóvenes (demandantes de tecnología, música, videojuegos) que acceden gratuitamente a través de la red.

h) Lucha contra el fraude y la piratería: Subyace claramente el interés de ambas plataformas de luchar contra la piratería programando contenidos lo suficientemente atractivos (tanto en música como en cine) que propicien un consumo directo y así evitar que esas mismas demandas (de películas o videoclips musicales) acaben siendo descargadas online a través de sistemas fraudulentos.

\section{Referencias bibliográficas}

AIMC (2011): Estudio "Navegantes en la Red", Asociación para la Investigación de Medios de Comunicación (AIMC), 25 de febrero de 2011, en www.aimc.es, (http://download.aimc.es/aimc/navred2010/macro2010ppt.pdf).

Asociación Europea de Publicidad Interactiva (EIAA), (2010): Séptima Edición del estudio "Mediascope Europe", en la sección news de la web de la European Advertising Association, (http://www.eiaa.net/news/eiaa-articles-details.asp?lang=5\&id=218.

Autor sin especificar, Europa Press, artículo titulado "La inversión publicitaria crecerá un 1,7\% en 2011 por el impulso de Internet”, en www.eleconomista.es, 26 de abril de 2011.

Carrillo Durán, Ma Victoria (2005): "La televisión digital. La metamorfosis publicitaria en la televisión digital”, Telos, nํ62, pp. 31-41.

Cotelo Oñate, Carlos (2010): "La televisión digital interactiva: contexto y efectos sobre la publicidad", Tesis Doctoral dirigida por el Profesor Dr. D. Julio Montero y Dr. Salvador Gómez, Universidad Complutense de Madrid, pp.42-48.

Cauberghe, Verolien, y De Pelsmacker, Patrick (2006): "Opportunities and Thresholds for Advertising on Interactive Digital TV: A View from Advertising Professionals", en Journal of Interactive Advertising, vol. 7, $\mathrm{n}^{\circ}$ 1, pp. 25-40, incluida en la página web http://jiad.org/vol7/no1/cauberghe/index.htm.

Comisión Europea (2004): "Comunicación interpretativa de la Comisión relativa a algunos aspectos de las disposiciones de la Directiva «Televisión sin fronteras» sobre la publicidad televisiva", DOCE C 102/2. Brussels, 28 de abril, en http://europa.eu/scadplus/leg/es/lvb/l24102.htm.

De la Rica, Enrique (2000): Sumario del libro Marketing en Internet, Madrid. Esic Editorial.

Delgado, Matilde y Fernández Quijada, David. (2007): “IPTV: estructura de mercado y tipología de la oferta en España", Zer, $\mathrm{n} \stackrel{0}{22}$, pp. 413-428.

Fernández Quijada, David (2007): “Industrias culturales en el entorno digital: una reformulación desde la praxis comunicativa”, Zer, № 22, pp.119-140.

Galán Fajardo, Elena y Del Pino Romero, Cristina (2010): “Jóvenes, ficción televisiva y nuevas tecnologías”, Área Abierta no 25, marzo, Universidad Carlos III de Madrid, pp. 1-17. 


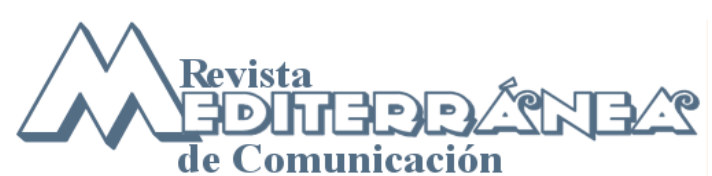

ISSN 1989-872X - Año2 (2011), pp. 72-102

Gálvez Guerrero, Javier (2007): "IPTV, Televisión digital interactiva sobre IP”. Profesor Josep Paradells Aspas, Telecom BCN - Escuela Técnica Superior de Ingeniería de Telecomunicaciones, Universidad Politécnica de Cataluña, Barcelona, 19 de diciembre, segunda revisión, pp.105-127.

Gómez Ponce, Mariela Ruth (2009): "El futuro de la televisión tradicional se juega en la red: Participación ciudadana y nuevos formatos mixtos de televisión en la red", 20 de abril, en www.cibersociedad.net

IAB (2011): Interactive Advertising Bureau (www.iabspain.net), "Estudio de Inversión en Medios Digitales en España 2010 IAB / PwC", 3 de marzo.

Levis, Diego (2006): "Sobre chat, máscaras y otros asuntos sobre el amor en Internet", Revista Electrónica Teoría de la Educación. Educación y Cultura en la Sociedad de la Información. Vol. 7. № 2, diciembre.

Levy, Shalom, y Nebenzahl, Israel d. (2006): "Programme involvement and television behaviour in interactive television", International Journal of Advertising, vol. 25, no 3, pp. 309-332.

Millán S., Jiménez M. y Ruiz del Árbol A. (2007): "La televisión personal en Internet crea su industria", Cinco Días, 6 de julio.

A. Prado, Emili, Franquet, Rosa, Ribes Francesc Xavier, Soto, María Teresa y Fernández Quijada, David. (2007): "La publicidad televisiva ante el reto de la interactividad", Questiones Publicitarias, vol. I, № 12, pp. 13-28.

PricewaterhouseCoopers (2010): "Global Entertainment and Media Outlook", publicado en Puro Marketing (http://www.puromarketing.com/18/8224/internet-videojuegos-television-pago-liderarancrecimiento-sector.html), el 19 de octubre de 2010.

Sáinz Macías, José Ignacio (Enero 2007): “Televisión por Internet, todo un reto”, Bit, no 160, , pp. 60-62.

Schumann, David w., Artis, Andy, y Rivera, Rachel (2001): "The future of interactive advertising viewed through an imc lens", Journal of Interactive Advertising, vol. 1, no 2, pp. 16-32.

The Cocktail Analysis (2010): "Televidente 2.0. Informe ejecutivo, Presentación de Resultados, $4^{\text {a }}$ Oleada", Madrid, junio.

Valero, Lucía (Septiembre 2010): "El mercado de Internet en Italia 2010", Oficina Económica y Comercial de la Embajada de España en Milán. Instituto Español de Comercio Exterior.

Vicente, Daniel. (Junio-Julio 2007): "Televisión por IP: Oportunidad de Negocio para los Telecos, Bit, no 163 , pp. 70-73.

\section{Notas}

[1] Muchos de los reality shows estructuran sus bases de concurso con una dependencia importante de los mensajes sms de la audiencia para 'nominar' o 'expulsar' a sus participantes. De este modo, los desenlaces van marcados por las tendencias, los gustos y la implicación de los televidentes. 
[2] En la última película de David Fincher, La Red Social, que describe cómo fueron los orígenes de la puesta en marcha de Facebook, un revolucionario sitio web que promueve la comunicación de personas unidas por afinidades, experiencias compartidas en el pasado, compañerismo de colegio o universidad, etc., se exponen las dudas que al principio les surgen a sus jóvenes creadores. En un simple diálogo se dice que la página de Internet, que comienza a cosechar un gran éxito desde su primer año de funcionamiento, y ya hoy acapara la atención de 500 millones de internautas, "(...) dejaría de ser guay si incluyera un anuncio de Pepsi (...)". Pero debe seguir adelante buscando patrocinios apoyándose precisamente en sus numerosos potenciales usuariosconsumidores.

[3] El product placement se conoce en España, como ya se ha mencionado por muchos profesionales, como emplazamiento de producto, es decir, la promoción de un artículo formando parte de los discursos oratorios o narrativos propios de espacios televisivos como talk shows, magazines de temas rosa, telenovelas, vídeos musicales, reality shows, o series. En estos casos, dependiendo respectivamente de si el que habla es un presentador-conductor, o un actor, nos encontramos con la mención de un artículo, o la inducción a su compra, con indicaciones más o menos precisas. En espacios como magazines, talk shows, o reality shows, el emplazamiento de producto se realiza con especificaciones amplias sobre la marca o el producto en cuestión, y siempre se advierte al espectador con un rótulo adicional (publicidad) que, como la clásica moscalogo, aparece y desaparece a conveniencia, aunque casi se diría que no es necesario por la obviedad de lo que se ve y se escucha en ese momento. En series, mini-series y otros programas de ficción, el actor pronuncia o consume un determinado producto y trata de adornar esta pequeña inserción publicitaria encubriendo su presencia mediante la participación del producto en el propio suceso narrativo (por ejemplo, consumir una marca de leche en una escena de desayuno o descanso de personal; la memoria nos lleva a series como Hospital Central o Farmacia de Guardia). En España, el emplazamiento de producto (que se ha puesto de moda nuevamente con la serie de Antena 3 TV Doctor Mateo) ha sido tolerado por el sector, o denunciado, según los casos, al no haber reglamentación al respecto. Se ha aprobado una Ley reguladora del emplazamiento de productos (Ley 7/2010 de 31 de Marzo General de la Comunicación Audiovisual), que regula en su artículo 17 dicho concepto. Entró en vigor el 1 de Mayo de 2010.

[4] Carlos Alberto Sánchez detalla el cómputo de abonados a Imagenio en un artículo de www.adslzone.com publicado en dicha página web el 11 de noviembre de 2010. Es importante señalar que cuando estos datos se den a conocer quizá se hayan publicado nuevas estadísticas.

[5] Por anuncios estáticos entendemos banners que permanecen en la misma posición dentro del diseño de la página web (aunque en su interior puedan desvanecerse objetos, escribirse mensajes en el momento, o se produzcan otros efectos). Los anuncios dinámicos cambian de posición, o bien aparecen o desaparecen en la misma página, variando su dirección y ubicación en la pantalla.

[6] Los Smartphones responden a una denominación común y muy de moda para los también llamados teléfonos móviles inteligentes con múltiples funciones, además de la propia comunicación interpersonal, el acceso a Internet, correo electrónico, GPS con sofisticados sistemas de localización (últimamente, aparte de las orientaciones para carreteras y destinos, incluyen recomendaciones de restaurantes cercanos) y un largo etcétera.

[7] Todos los productos de Telefónica (TV, Internet, Telefonía Fija, Telefonía Móvil) han pasado a denominarse Movistar. 
[8] “¿Qué es la IPTV?”, en Boletín ‘Sociedad de la Información’. Fundación Telefónica. 11 de junio de 2007. En la realización de la ficha colaboran Francisco Javier López Benito de Telefónica I+D y José Manuel Pascual Martín de Telefónica España. Las declaraciones de un responsable de la compañía sobre este tema las podemos escuchar y ver en www.youtube.com, en un enlace colgado el 4 de abril de 2008.

[9] Boletín ‘Sociedad de la Información'. Fundación Telefónica. 11 de junio de 2007.

[10 La "pegadiza" denominación de Imagenio (ahora, Movistar Imagenio) parece originarse en virtud de una hábil combinación de dos palabras imagen + genio, concepto dual que apela claramente a la creatividad a la hora de trabajar o "manejar" imágenes. Desde este apelativo se invita al televidente a ser su propio genio construyendo imágenes y sonidos a conveniencia. La televisión a la carta conformada a través de esta plataforma de Telefónica parece casar muy bien con el nombre de Imagenio.

[11] Baby TV es el canal de televisión infantil para bebés hasta tres años de edad. Emite 24 horas al día programas de entre dos y diez minutos de duración, con los que pretende estimular las capacidades de los bebés y promover la interacción entre padres e hijos. La programación del canal se realiza con la colaboración de psicólogos y especialistas en desarrollo infantil. Información publicada en la web zonagenio.com, portal de noticias de Imagenio, el 16 de Julio de 2008.

[12] La diferencia básica entre tráiler y teaser se circunscribe esencialmente a su duración. El tráiler es más largo, 1 minuto o más, mientras el teaser se prolonga por unos segundos, sin alcanzar nunca los sesenta. Se ha puesto muy de moda entre los especialistas en marketing cinematográfico dado que tiene mayor capacidad de atracción para causar el interés suficiente en el potencial espectador. Su magnetismo reside mayormente en el estilo visual que se elige: imágenes fugaces separadas por fundidos a negro que generan un misterio o enigma entre el público, secuencias aparentemente inconexas pero muy seleccionadas, las más espectaculares de cada cinta, que no siguen el sentido narrativo de la obra original pero que provocan una necesidad de resolución teniendo que acudir a la sala para saciar la curiosidad. Una de las críticas que suscita este tipo de fórmula publicitaria es construir un imaginario ficticio, un cúmulo de expectativas que, más tarde, cuando concluye el visionado del film, no están a la altura de lo esperado. Este efecto desilusionante para el espectador no preocupa tanto a los productores que ya han visto recompensa en taquilla pues la película ya habrá sido vista por miles de espectadores que entraron en las salas con ganas de conocer las respuestas a las "preguntas visuales" formuladas por el tráiler o teaser.

[13] Informe "Descubre la segmentación con Orange Advertising Network". Wunderloop. Orange. Citado por la Compañía en su página web www.orange.es. 2010.

[14] Por claim entendemos el cierre de un anuncio donde normalmente se da el consejo de consumir el citado producto o servicio subrayando el mensaje con algún eslogan. Se presenta también el logo y/o denominación del anunciante y, si cabe, otras referencias como web, direcciones, teléfonos y otros datos. 